\title{
Evaluation of Groundwater Quality Of Bachupally, Nizampet And Pragathinagar Village
}

\author{
S. Venkatcharyulu ${ }^{1}$, Rathod Ravinder $^{2}$, Y. Kamala Raju $^{3}$ \\ ${ }^{1}$ Assistant Professor Gokaraju Rangaraju Institute of Engineering and Technology Hyderabad, India \\ ${ }^{2}$ Assistant professor Gokaraju Rangaraju Institute of Engineering and Technology Hyderabad, India \\ ${ }^{3}$ Assistant professor Gokaraju Rangaraju Institute of Engineering and Technology Hyderabad, India
}

\begin{abstract}
Water is an important nature gift for the human life hence study of drinking water quality is essential requirement in the residential area. In this paper study area has latitudes and longitudes of Bachupally $17.5151 \mathrm{~N}$ and $78.3855 \mathrm{E}$, Nizampet17.5513N and $78.3855 \mathrm{E}$, Pragathinagar $17.5186 \mathrm{~N}$ and 78 3963E it is integral part of the Hyderabad situated in the Telangana state , India . Study area contain mixed type of habitants such as agricultural developing formers, pharma- industries employs and general living official and business people. Since the land occupied by the several type peoples activities there are many problems with ground water resources and surface water contamination. Its require to test the water quality(WQ) In the study area to know the more extent of quality problems. WQ test has conducted for the Alkalinity, PH, hardness of water, and turbidity etc. water quality helps, The local authorities to solve the certain problems in the region and adopt the certain methods to solve the problems. Samples are collected from the Various places from the Nizampet, Bachupallly and Pragathinagar regions. Around 27 number of ground water samples (GWS) are collected and all of them selected for the analysis. Experiments are conducted for the each sample and obtain the result. It is compared with the standard values. The result obtained from the various ranges of chlorides, nitrates, total dissolved solids,, conductivity values , $\mathrm{pH}$ For the different areas of study region are clearly mentioned in the result discussion session. The water quality for the Various places from the Nizampet, Bachuplly and Pragathinagar clearly discussed in the results. finally remedial measures to be adopted for the improvement of the quality of water.
\end{abstract}

\section{Introduction}

Water is main ingredient of the human life which has contain the minerals and metals. Sufficient quality of metals and minerals is require to the Human body and some quantities of metals very harm to the health. Water is predominant source on the earth which influence all human health. Hence the Quality of water is important and need to trace out metal content and chemical contamination, where pollution is more. Pollution to water sources is mainly due to the various human activities but naturally available water has abundant mineral quality . Entire globe has $71 \%$ of water and 21 $\%$ earth . Study area has surrounded by the industries, some agricultural field and newly developed improper residence sewage drains. It need to study the quality and quantity of the related place and its surroundings. Since the area has fully developed due to modernization and is having more scarcity of water. study areas Ground water samples (GWS) are collected from prime location where it is possibility of the pollution. Water contamination tests are conducted using chemical analysis. chemical content related to $\mathrm{PH}$, alkalinity, chlorides, Hardness and Heavy metals. All CWS tested and chemical analyzed in the laboratory and given the result, weather the sample is fit for the drinking purpose or not. After the receiving the results of test GWS are compare with the standard values.

\section{Study Area}

The study area has latitudes and longitudes of Bacupally $17.5151 \mathrm{~N}$ and $78.3855 \mathrm{E}$, Nizampet17.5513N and $78.3855 \mathrm{E}$, Pragathinagar $17.5186 \mathrm{~N}$ and $783963 \mathrm{E}$ it is integral part of the Hyderabad situated in the Telagana state, India. Study area contain mixed type of habitants such as agricultural developing formers, and contain more number of pharma- industries, occupied by employs and general public regular official and farmers. Since the land occupied by the several type peoples activities there are many problems with ground water resources and surface water contamination. Its require to test the water quality (WQ) In the study area to know the more extent of quality problems. WQ test has conducted 
for the Alkalinity, $\mathrm{PH}$, hardness of water, and turbidity etc. Water quality helps them, authorities to solve the certain problems in the region and adopt the certain methods to solve the problems. Samples are collected from the Various places from the Nizampet, Bachuplly and Pragathinagar regions. Around 27 ground water samples (GWS) are collected and all of them selected for the analysis. Experiments are conducted for the each sample and obtain the result.

\section{Literature review}

(Water samples are collected different areas of Himayat sagar for checking water quality done by k.padmaja et.al (2017 a, b). Evaluating the quality of water and giving some ranking to the water quality is know as water quality index.. Total 40 sample collected before monsoon an after monsoon and analyzed by chemical tests done by Bob pears et.al (2016, a, b). Different well selected for the collecting 10 samples based on the Topography of the area By K. Niranjan Kumar et.al((2009). Nearly fifteen papers are analyzed for the water quality analysis which has mentioned in the references. Sudhakar Gummadi et al. (2014, a, b, c) discussed different parameters of drinking water has ranked and indexed in the order to known the WQ parameters such as TDS, dissolved oxygen etc in the Bapatal village ,A.P,INDIA. water quality in the musi river is polluted and pollutions are compared with compared with Indian standard manual. The standard values relate to TDS and other chemical parameters by Akhil Gurijala et.al (2020a, b, c). Severe contamination for the ground water resources from in the industries and untreated sewage and local leacheat from the landfills by Ranjan K. Ray (2019).

materials and Aerogel and discussed some assessment parameters affecting the energy-efficient criteria and concluded that the energy-efficient materials should be evaluated in terms of their local availability, renewable resources used in the manufacturing, thermal conductivity and cost.

(L. Aditya et al. 2016) have discussed that due to the growth of Population industrialization is increasing by that $\mathrm{CO} 2$ emission is also increasing which leads to raising the Earth average temperature about $1.1-6.4{ }^{\circ} \mathrm{C}$ by the end of 2100 . It could cause severe impact on the environment and human life, so in all the sectors it is focused to bring down the energy emission mainly in our construction industry by proper insulation strategies plays a vital role. Aditya has considered some materials like fiber glass, mineral wool, foam, XPS and EPS as building

\section{Methodology}

The Lab analysis was conducted for the GW and checked for the collected WQ Analysis from the study area .Three places ( study regions) are selected for the WQ test, and From each region 9 samples are collected and analyzed for the chemical pollution. After each samples result obtained are tabulated and compare with the standard values of water quality (IS standard). The materials and method adopted can be shown in the tabular column. Table 1. In this table first column is related to the WQ test id, second column shows the Nname of the test third column shows the material adopted for the test and final column Represents the range of values allowed in water. A flow chart is shown for the dataflow and method of execution shown Fig.1 study area has some industries surrounded GWS have collected at reference of Latitude(N) and Longitude(E) locations. Samples with the given location are named id number and further referred in the graphs.. Several papers are studied and most of them related WQ studies. some of the water quality tests literature mentioned here. yadave et.al(2010) did the quality of

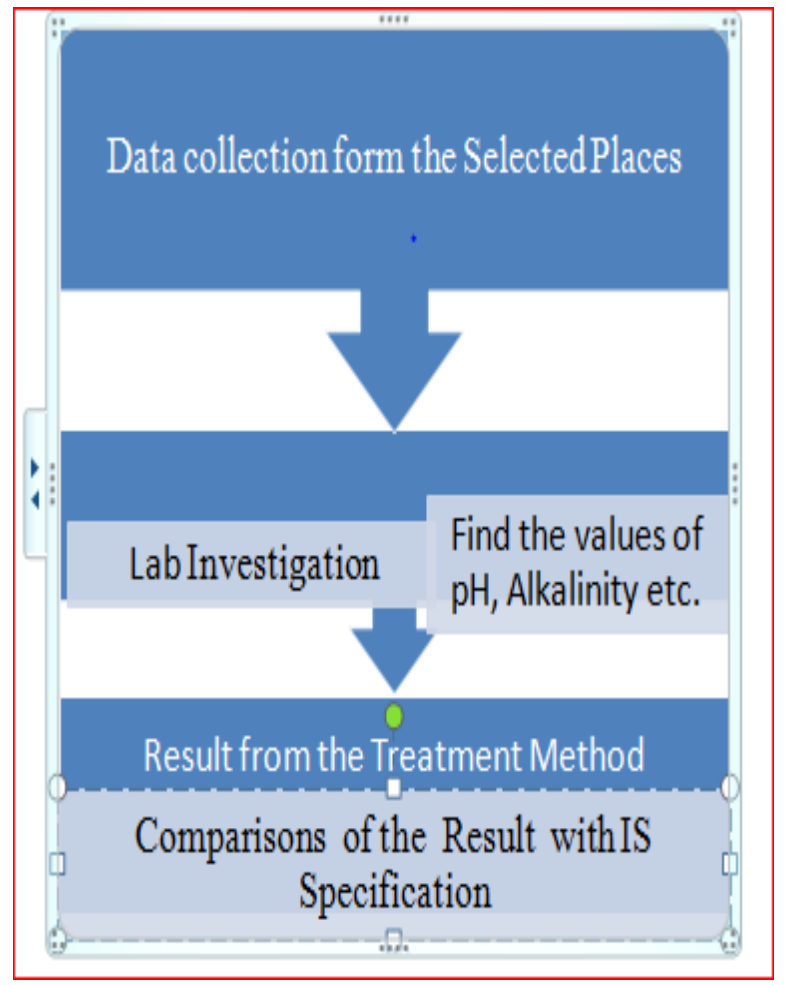

Fig 1. Showing the Work Flow Methodology

water test and Shahabad (India) . shah et.al (2012) most of the samples of water suitable for he dinking purpose in Gujrat (India). k.Niraja (2012) quality compare with I.C.M.R and found good for drinking in Bhopal. (India. $\mathrm{K}$. Ramesh et.al (2012)(India) did water test for the six different places found it good quality. Subhajyoti.Das(2011) Water is precious, River Ganges should be prevented from the pollution.

\section{Ground water Quality}

WQ of the study region has need to evaluate for the safety of villagers. It is observed pollution in surface water.. Experts investigate CWS from the location as per Latitude and Longitude and checked quality of water. Study area has small lakes and storage tanks which over flows with contamination and percolating. This is one of the reason for the (GWP) Ground-water-pollution and need of the chemical tests in the study area. 


\section{Contamination of Groundwater (Gwc)}

Bellow earth surface, water contamination occurs because of waste products like gasoline, chemicals , liquid generated from the road laying and chemicals from the fertilizers seeps into ground and WQ finally unsafe and unfit for daily usage. Diluted pollutants contaminated BSW. The lists of materials that cause hazardous to ground water are Chemicals that used for crops over a long period (Fig..3), leakage and rain water mix with road chemical, pollutants released from the factory, leakages from the sewerages and garbage (Fig. 2). Used motor olis etc.

\subsection{List of Ressources}

Water Contaminations :1)Land filing with more effluents especially wet waste 2) Fuel filling stations which storage the huge quantity of the fuel store in the ground..C) Metals like arsenic, chemicals like Fluoride can easily pollute the surface and ground water. All these are reflecting On the human health and cause chronic problems

\subsection{Effects the BSW(Bellow surface water) in the study area}

Due to the pollution of sewerage water in BSW will cause the hepatitis, dysentery. Similarly due to the leakages from septic tank pollute BSW water and caused the hazardous to both human and animal life. pollutants form the industries flows over the land surface seeps in to the ground will increase the metal and chemical content that leads BSW a serious effect. And ultimately not use full for the human utility like drinking and other hygienic purposes. Farmer used many kind of the fertilizers for the i) Crop growth, ii) To kill insects iii) Increases the strength of the soil nitrites etc. since these chemical applying for the crops in very frequent intervals and used in huge quantities.. Study area Pragathinagar, Nizapet and Bachulpply villages Fig.3b ( Fig 4 to Fig.10) are near Hyderabad (India) sample are collected 9samples from each place and total 27 numbers analyzed in the lab tested in study area (Fig. 3a) for contents in BSW such as $\mathrm{pH}$ ( for acidic and basic test.), D.O., (diluted oxygen ) El.C. (electrical conductivity) TDS (Total dissolved solvents)., alkalinity bases present in the water, (know the turbidity, $\mathrm{Ca}$ (calcium) and $\mathrm{Mg}$ magnesium, hardness, total hardness, $\mathrm{N}(\mathrm{O}) 3$-nitrate, $\mathrm{Fl}$ fluoride, iron and $\mathrm{Cl}$-chloride have been tested. It has been compared with standards (IS.10500-2012). Shown in Table 2 Detail of ground water samples (GWS) and CWS with Latitude (Lat)N and Longitude(Lon)E Table 2 location. Samples collected from the bore wells and given ID number for the easy identification of specific area.

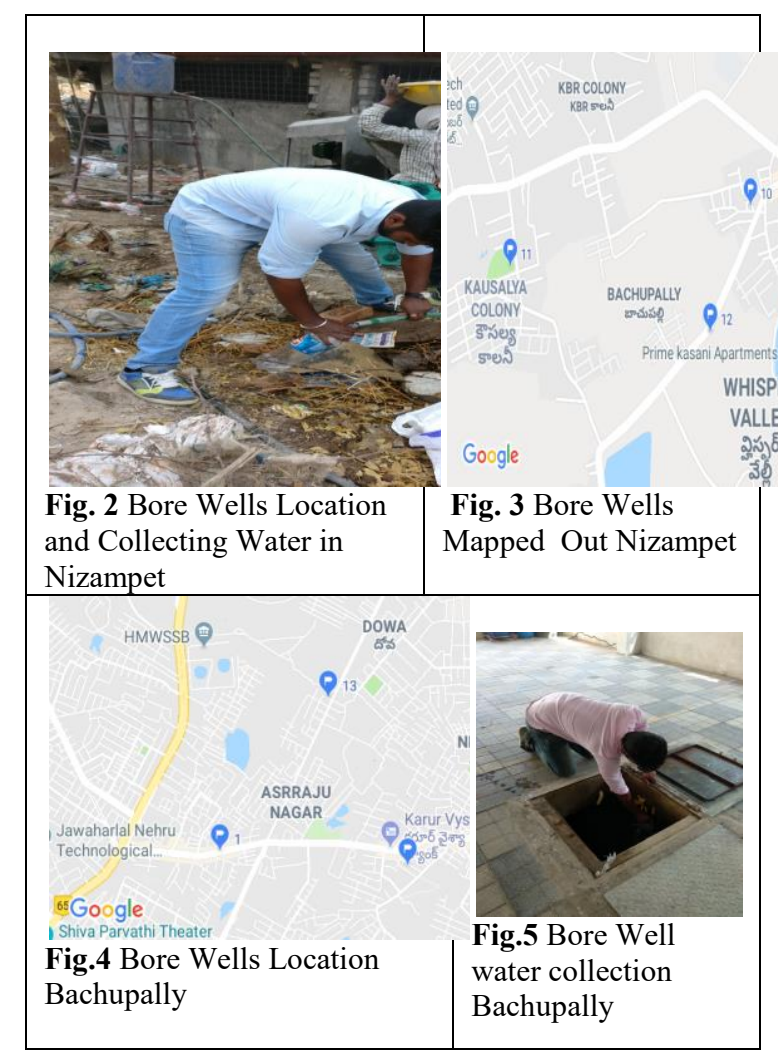

\section{Chemical test for WS(water samples}

$7.1 \mathrm{pH}$ test should be complete within two hr of collection water sample (WS). $\mathrm{pH}$ of water is changes because of content co2 from atmosphere mixed in the WS. pH device (meter) for the measurement of $\mathrm{pH}$. (Refer Fig.. 8(a)) . PH value refer with Id numbers of samples .

7.2 Turbidity was analyzed using the Nephelometric Turbidity meter. The combined reagent is prepared with the Hexamine and Hydrazinium Sulphate, with this solution the equipment is calibrated. Then collected samples turbidity is analyzed (Fig. 10) and compared with standard values.

7.3 (E.con) electrical conductivity calculated by taking $1 / 1000$ (Mall samples it is with in limit .K.C.L) is used for the test of BWS (Fig.8(b)) . All the values are observed And compared how much the values are differ. 7.4. Alkaline limit is prime important to decide the water nature whether it is in acidic in nature or he basic nature./vol. of $20 \mathrm{ml}$ samples tested with so 2 and phenol-phthalein, methyl solution tuned for the test of BWS (Refer- Fig.10) it is calculated as using Alkalinity estimated, in milligram ( $\mathrm{mg})$, calcium carbonate $(\mathrm{CaCO} 3 /$ liter $)=$ volume of acid $\mathrm{x}$ normality $\mathrm{x} /$ volume of BWSS. 


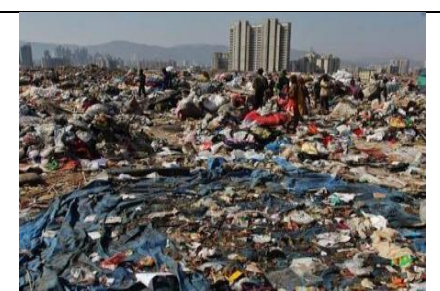

Fig . 6 Solid Wastes

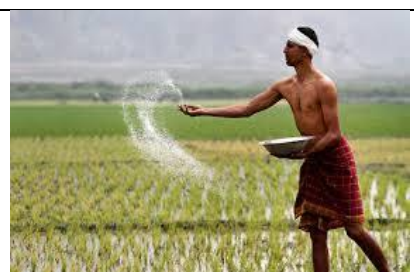

Fig. 7 Agricultural activités

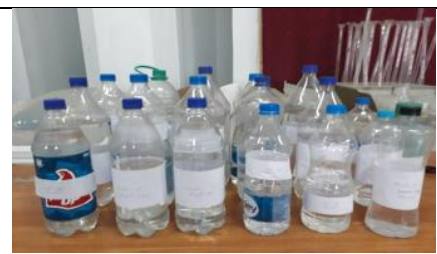

Fig. 8 Samples from the study area

\begin{tabular}{|c|c|c|c|}
\hline S No. & $\begin{array}{l}\text { Chemical } \\
\text { Test }\end{array}$ & Material need for Test & $\begin{array}{l}\text { Allowable range of quality of water(IS } \\
10500-1991) \mathrm{mg} / 1\end{array}$ \\
\hline 1 & PH & $\begin{array}{ll}\text { 1. } & \text { Distilled Water } \\
\text { 2. } & \text { Buffer Capsules-4.0 } \\
\text { 3. } & \text { Buffer Capsules-9.2 }\end{array}$ & 6.5 to 8.5 \\
\hline 2 & Turbidity & $\begin{array}{ll}\text { 1. } & \text { Hexamine } \\
\text { 2. } & \text { Hydrazinium Sulphate } \\
\text { 3. } & \text { Distilled Water }\end{array}$ & 5-10 N.T.U \\
\hline 3 & Alkanity & $\begin{array}{ll}\text { 1. } & \text { Sulphuric Acid 0.1 N } \\
\text { 2. } & \text { Methyl Orange Indicator } \\
\text { 3. } & \text { Phenopthalein }\end{array}$ & $200 \mathrm{~m} . \mathrm{g} / \mathrm{lit}$ \\
\hline 4 & Chlorides & $\begin{array}{ll}\text { 1. } & \text { Potassium Chromate } \\
\text { 2. } & \text { Silver Nitrate } \\
\text { 3. } & \text { NaCl solution }\end{array}$ & $250 \mathrm{~m} \cdot \mathrm{g} / \mathrm{lit}$ \\
\hline 5 & Nitrates & $\begin{array}{l}\text { 1. Potassium Chromate Sulphuric Acid } \\
\text { 2. NaCl solution } \\
\text { 3. UV-Visible spectrophotometer }\end{array}$ & 45 \\
\hline
\end{tabular}

7. $5(\mathrm{Cl})$ chloride evaluated using k.cl sol. Combined to water BWSS and adopted lab procedure to obtain the chloride test. (Fig. 12). In the study region it is observed in the limited Range.

7.6. Spectra-photometric- méthode-Nitrate content determination: $\mathrm{kno}_{3}$ sol. and quantity of nitrate keep above $100^{\circ} \mathrm{C}$ about one day . found out with standard laboratory laboratotary procedure. More value of nitrate value Id numbers are noted separately .

7.7 A curve plotted for the absorption and concentration of RWSS to obtain the absorption . General This method useful water quality and test carried out in the lab with proper procédural masure.

7.8 Location of samples Table 2 and collected semples Table 4 Is show. The guidelines for the comparison is shown in Table 3.

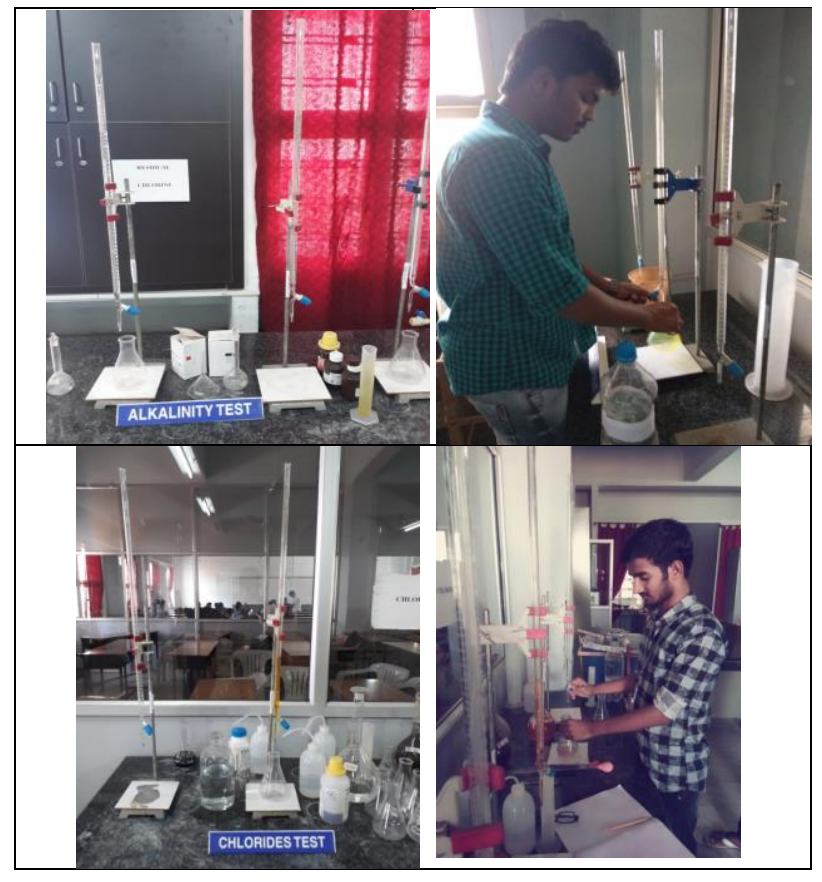

Fig. 9 Turbid meter, pH Meter 


\begin{tabular}{|c|c|c|c|c|c|}
\hline \multicolumn{6}{|c|}{ Table 2 Details of GWS (Grounds Water Sources) } \\
\hline $\begin{array}{l}\text { I . D of Collection } \\
\text { point }\end{array}$ & $\begin{array}{l}\text { Name of the } \\
\text { Collection } \\
\text { Area }\end{array}$ & $\begin{array}{l}\text { Collection } \\
\text { ressourcés }\end{array}$ & $\begin{array}{l}\text { Level of } \\
\text { ground } \\
\text { water (Feet) }\end{array}$ & $\begin{array}{l}\text { N(Latitude) } \\
\text { Location in } \\
\text { Dégrée and } \\
\text { seconds }\end{array}$ & $\begin{array}{l}\text { E (Longitude) } \\
\text { Location in } \\
\text { Dégréé and } \\
\text { seconds }\end{array}$ \\
\hline 1 & Nizampet & Bore Well & $250^{\prime}$ & 17.553682 & 78.388100 \\
\hline 2 & Nizampet & Bore Well & $290^{\prime}$ & 17.518345 & 78.463113 \\
\hline 3 & Pragathinagar & Bore Well & $210^{\prime}$ & 17.513301 & 78.393431 \\
\hline 4 & Pragathinagar & Bore Well & $70^{\prime}$ & 17.514024 & 78.398157 \\
\hline 5 & Pragathinagar & Bore Well & $180^{\prime}$ & 17.514261 & 78.390717 \\
\hline 6 & Pragathinagar & Bore Well & $240^{\prime}$ & 17.519341 & 78.398716 \\
\hline 7 & Pragathinagar & Bore Well & $120^{\prime}$ & 17.532561 & 78.394310 \\
\hline 8 & Bachupally & Bore Well & $250^{\prime}$ & 17.543662 & 78.472957 \\
\hline 9 & Bachupally & Bore Well & $100^{\prime}$ & 17.543698 & 78.372641 \\
\hline 10 & Bachupally & Bore Well & $150^{\prime}$ & 17.538246 & 78.363548 \\
\hline 11 & Bachupally & Bore Well & $80^{\prime}$ & 17.528616 & 78.358119 \\
\hline 12 & Bachupally & Bore Well & $270^{\prime}$ & 17.534938 & 78.365553 \\
\hline 13 & Nizampet & Bore Well & $300^{\prime}$ & 17.506951 & 78.378053 \\
\hline 14 & Nizampet & Bore Well & $80^{\prime}$ & 17.514267 & 78.384930 \\
\hline 15 & Nizampet & Bore Well & $150^{\prime}$ & 17.520348 & 78.367415 \\
\hline 16 & Nizampet & Bore Well & $240^{\prime}$ & 17.503682 & 78.588100 \\
\hline 17 & Nizampet & Bore Well & $270^{\prime}$ & 17.518345 & 78.463113 \\
\hline 18 & Pragathinagar & Bore Well & $201^{\prime}$ & 17.513301 & 78.693431 \\
\hline 19 & Pragathinagar & Bore Well & $990^{\prime}$ & 17.514024 & 78.398157 \\
\hline 20 & Pragathinagar & Bore Well & $683^{\prime}$ & 17.514261 & 78.490717 \\
\hline 21 & Pragathinagar & Bore Well & $220^{\prime}$ & 17.519341 & 78.398716 \\
\hline 22 & Pragathinagar & Bore Well & $120^{\prime}$ & 17.532561 & 78.694310 \\
\hline 23 & Bachupally & Bore Well & $210^{\prime}$ & 17.543662 & 79.372957 \\
\hline 24 & Bachupally & Bore Well & $320^{\prime}$ & 17.543698 & 79.772641 \\
\hline$\frac{25}{25}$ & Bachupally & Bore Well & $150^{\prime}$ & 17.538246 & 79.063548 \\
\hline 26 & Bachupally & Bore Well & $80^{\prime}$ & 17.528616 & 78.358119 \\
\hline 27 & Bachupally & Bore Well & $700^{\prime}$ & 17.534938 & 78.365553 \\
\hline Collected water sa1 & (CWS) & & & & \\
\hline
\end{tabular}

\begin{tabular}{|l|l|l|l|l|l|l|l|}
\hline \multicolumn{7}{|l|}{ Table 3 The average values of parameters for every sample (mg/l) } \\
\hline $\begin{array}{l}\text { Sample ID } \\
\text { No. }\end{array}$ & PH & Turbidity & $\begin{array}{l}\text { Conductivi } \\
\text { ty }\end{array}$ & Alkanity & Chlorides & Nitrates & TDS \\
\hline 1 & 7.66 & 0.816 & 50.33 & 141.66 & 133.67 & 12.3 & \\
\hline 2 & 7.36 & 0.866 & 47.66 & 161.66 & 71.48 & 24.15 & 327 \\
\hline 3 & 7.42 & 0.833 & 48.33 & 151.66 & 87.44 & 13.2 & 258 \\
\hline 4 & 6.67 & 0.883 & 48 & 168.33 & 128.79 & 5.11 & 356 \\
\hline 5 & 6.38 & 1.383 & 47 & 156.66 & 110.48 & 26.15 & 356 \\
\hline 6 & 7.5 & 1.033 & 47 & 125 & 24.45 & 64.69 & 290 \\
\hline 7 & 6.65 & 0.833 & 49.33 & 123.33 & 292.47 & 35.55 & 343 \\
\hline 8 & 7.27 & 0.966 & 47.33 & 175 & 277.66 & 52.78 & 225 \\
\hline 9 & 7.26 & 0.95 & 48.33 & 163.33 & 73.58 & 16.47 & 213 \\
\hline 10 & 7.37 & 0.983 & 49.33 & 171.66 & 260.7 & 17.29 & 255 \\
\hline 11 & 7.05 & 0.966 & 50.33 & 186.66 & 121.11 & 88.54 & 358 \\
\hline 12 & 6.35 & 0.883 & 49.33 & 161.66 & 84.99 & 74.52 & 310 \\
\hline 13 & 6.8 & 0.9 & 49.66 & 140 & 80.94 & 21.74 & 222 \\
\hline 14 & 6.41 & 0.916 & 49 & 118.33 & 40.17 & 68.74 & 312 \\
\hline 15 & 6.96 & 0.95 & 48 & 175.66 & 145.79 & 36.44 & 356 \\
\hline 16 & 7.56 & 0.719 & 47.33 & 141.66 & 133.67 & 23.3 & 234 \\
\hline 17 & 7.36 & 0.669 & 40.66 & 161.66 & 71.48 & 26.15 & 257 \\
\hline 18 & 7.42 & 0.833 & 4433 & 151.66 & 87.44 & 24.2 & 243 \\
\hline 19 & 6.67 & 0.883 & 49 & 168.01 & 118.79 & 9.11 & 320 \\
\hline 20 & 6.38 & 1.383 & 48 & 146.62 & 100.48 & 29.15 & 255 \\
\hline 21 & 7.5 & 1.033 & 49.5 & 124.3 & 22.45 & 63.69 & 290 \\
\hline 22 & 6.65 & 0.833 & 45.33 & 121.12 & 282.47 & 65.55 & 333 \\
\hline 23 & 7.27 & 0.966 & 42.33 & 160.12 & 287.66 & 64.78 & 456 \\
\hline 24 & 7.26 & 0.95 & 46.33 & 163.33 & 173.58 & 46.47 & 356 \\
\hline
\end{tabular}




\begin{tabular}{|l|l|l|l|l|l|l|l|}
\hline 25 & 7.37 & 0.983 & 42.33 & 181.66 & 160.7 & 40.29 & 243 \\
\hline 26 & 7.05 & 0.966 & 33.33 & 180.66 & 141.11 & 58.54 & 220 \\
\hline 27 & 6.06 & 0.93 & 48 & 170.66 & 154.79 & 43.44 & 290 \\
\hline
\end{tabular}

\begin{tabular}{|c|c|c|c|}
\hline \multicolumn{4}{|c|}{ Table 4. Showing (I.S ) Standard (10500- 2012) Spécification values } \\
\hline S No. & $\begin{array}{c}\text { Chemical } \\
\text { Test }\end{array}$ & Material need for Test & $\begin{array}{c}\text { Allouable range of } \\
\text { qualité of water(IS } \\
10500-1991) \mathrm{mg} / 1 \\
\end{array}$ \\
\hline 1 & $\mathrm{PH}$ & $\begin{array}{ll}\text { 4. } & \text { Distilled Water } \\
\text { 5. } & \text { Buffer Capsules-4.0 } \\
\text { 6. } & \text { Buffer Capsules-9.2 }\end{array}$ & 6.5 to 8.5 \\
\hline 2 & Turbidity & $\begin{array}{ll}\text { 4. } & \text { Hexamine } \\
\text { 5. } & \text { Hydrazinium Sulphate } \\
\text { 6. } & \text { Distilled Water }\end{array}$ & 5-10 N.T.U \\
\hline 3 & Alkanity & $\begin{array}{ll}\text { 4. } & \text { Sulphuric Acid } 0.1 \mathrm{~N} \\
\text { 5. } & \text { Methyl Orange Indicator } \\
\text { 6. } & \text { Phenopthalein }\end{array}$ & $200 \mathrm{~m} . \mathrm{g} / \mathrm{lit}$ \\
\hline 4 & Chlorides & $\begin{array}{ll}\text { 4. } & \text { Potassium Chromate } \\
\text { 5. } & \text { Silver Nitrate } \\
\text { 6. } & \text { NaCl solution }\end{array}$ & $250 \mathrm{~m} . \mathrm{g} / \mathrm{lit}$ \\
\hline 5 & Nitrates & $\begin{array}{l}\text { 4. Potassium Chromate Sulphuric Acid } \\
\text { 5. NaCl solution } \\
\text { 6. UV-Visible spectrophotometer }\end{array}$ & 45 \\
\hline
\end{tabular}

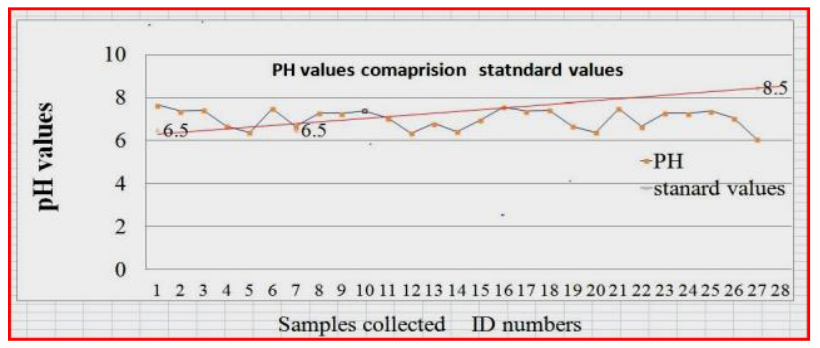

Fig.10 Graph showing PH value comparison with standard values

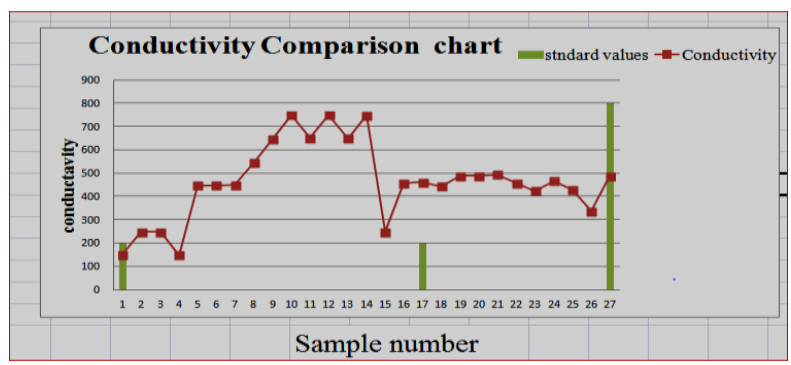

Fig . 11 . Graph showing conductivity value comparison with standard values

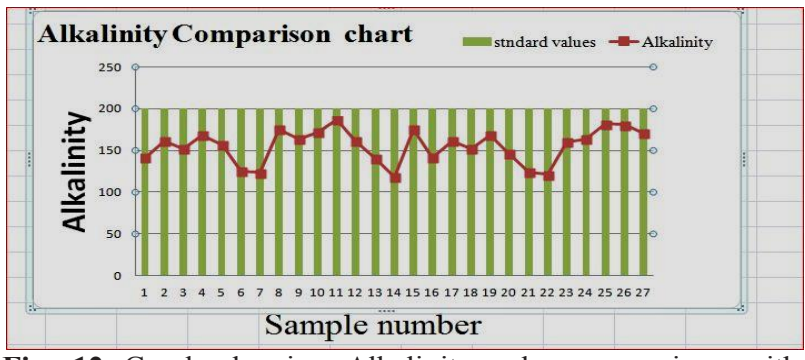

Fig. 12 Graph showing Alkalinity value comparison with standardvalues

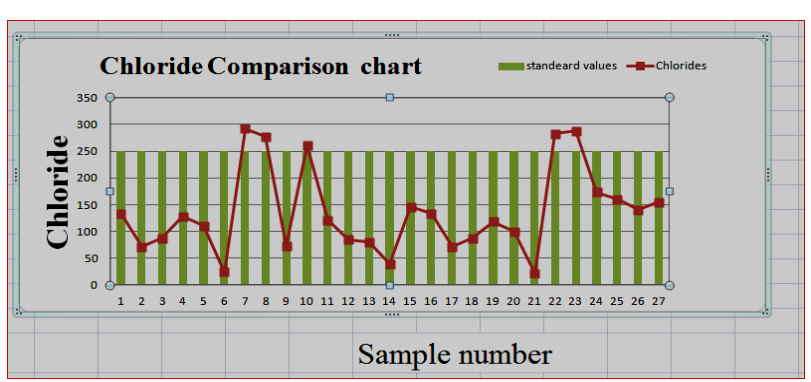

Fig .13 Graph showing chlorides value comparaison with standard values 


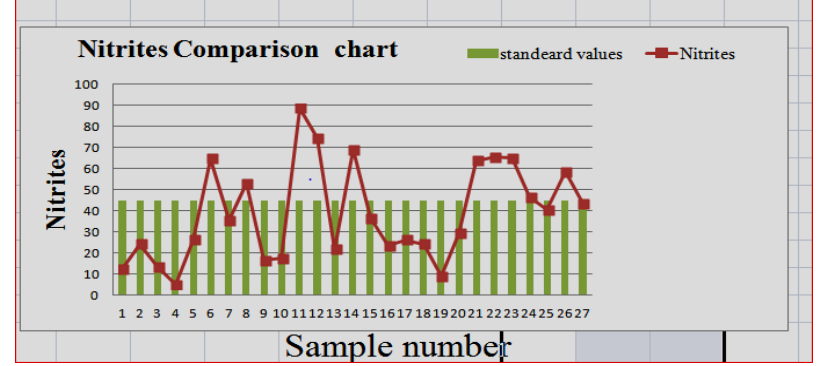

Fig . 14 Graph showing Nitrates value comparison with standard values

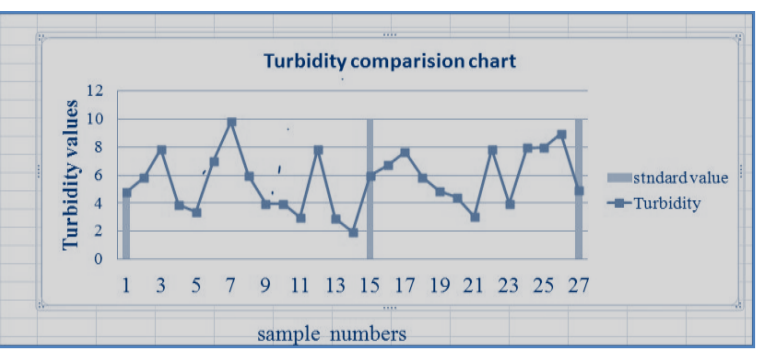

Fig . 15 . Graph showing turbidity value comparaison with standard values

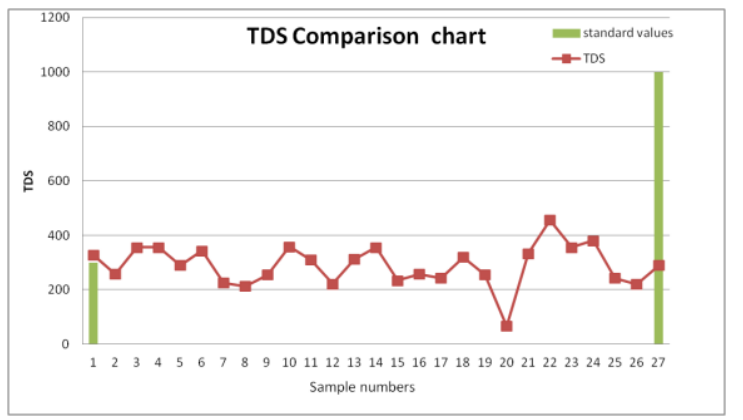

Fig 16. Graph showing TDS value comparison with standard values

\section{Results}

Groundwater studies have been carried out to détermine according to the standard of consuming Domestic purposes especially in. Paragathinagar, Nizampet and Bachupally villages(INDIA), the $\mathrm{pH}$ values of CWS ranges 6.35 to 7.66 as shown in the Table-4. Except for the sample-5, semple-12 \& semple-14,26,27 are near to the acidic nature. $\mathrm{pH}$ levels with in the limits. It is suggested that remaining 11 semples can be used for drinking purpose. $\mathrm{pH}$ ranges of 6.5 hazardous to Heath (acidité). For all (GWS) grounds water semples chlorites values estimâted between 10 - $161 \mathrm{mg} / \mathrm{l}$ which are permissible limits. Nitrates values fro Id. No ,12 14,,21, 22, 24,26 are above High values and standard is between 5 - $74 \mathrm{mg} / \mathrm{l}$. and max limited to $45 \mathrm{mg} / \mathrm{l}$. from results 4 (CWS ) High Nitrate values was due to more irrigation and Domestic waste over the land surface, agricultural fertilizers mixed in to water bodies. More content of Nitrate presence in water cause health problems like, goiter, and blood pressure, tensions. The Chloride ranges from 24 to $250 \mathrm{mg} / 1$ samples were under permissible limits.Id no $6,8,223,23$ is more chlorine ,turbidity, alkalinity TDS value for the satisfied usage values (all CWS are satisfied range

\section{Conclusion}

Since continues dumping of the liquid waste and chemicals over the land fillings are caused extensive contaminating to the ground water and other water resources. Hence control measures towards chemical and physical are to taken in the study area. Some of the methods will consider preventing the water pollution and keeping the hygienic ground WQ they are

- Construction and laying sewage lines with proof leak materials and immediate rectification of the leakages. Pragatinagar region. Hyderabad, T.S, India.

- Avoid the open drainage flows in the villages near the Nizampet and Bachuplly area, Hyderabad, T.S,India

- Avoid excess usages of chemical application to the crop and other in the Bachcupally near surrounding .

- Chlorination excessive for the drinking and ground water is observed in some samples can be rectified by de-chlorination methods placed in proper locations Future there is wide scope of check the ground water and surface water quality in the study area.

\section{Acknowledgments:}

Research work has done with the supporting from the GRIET Institution for the laboratory tests support . For conducting the sample collections supported by the local authorities from panchayat, municipal departments . I would thank to all the support staff and Environmental professors from the GRIET for their support.

\section{References}

1. Gummadi, S., Swarnalatha, G.Venkataratnamma, V. and Vishnuvardhan, Z. (2014), “ Water coastal Andhra Pradesh, India”, International Journal of Environmental Science, 5(1), 23-33. 2014.5.1.23.

2. Gurijala1 Akhil, D. Satish Chandra, M.V.Raju, SS. Asadi (2020), "Assessment of water Qauality for the Environmental Management" , IJAST, 29 7248-7258. 2020.29.3.7248.

3. I.S 10500 (2012)., Central Ground Water Board, (CGWB), Indian Standard Drinking Water specification Indian Standard, Hyderabad, India.

4. Kumar . K. Niranjan , (2009) , " Preliminary investigations of ground water quality in Hyderabad city, Andhra pradesh", int. Journal of Chem. Sci.. 7(1), 59-70. 2009.7.1.59.

5. Kumar M.S., Raju, M.V., Palivela, H., Venu Ratna Kumari, G. (2017), "Water quality scenario of urban polluted lakes - A model study", International Journal of Civil Engineering and Technology, 8(5), 297- 302.2017.8.5.297.

6. Murthy M.N.(1995)"Environmental Regulation in the Developing World: A Case Study of European Community and International Environmental Law, IOSR Journaliosrjournals.org , 4 of India" Review (5), 330-337. 1995.4.5.330. 
7. NEERI (1986), "Manual on water and waste water analysis", P-340 ,National Environmental Engineering Research Institute, Nagpur, India.

8. Tummala Suresh Kumar, Kosaraju Satyanarayana, Materials Today: Proceeding, 26 (2), 3228-3233, (2020).

9. Padmaja .K, Jyotsna Cherukur, M.Anji Reddy2017), "Assessment of Water Quality of Himayathsagar Lake in Hyderabad - A Case study", IOSR Journal of Env. Science, 11(1), 1822. 2017.11.1.18.

10. Saraswathi B, Radhika P, Vinoda Y (2016) "Assessment of ground water quality of LB Nagar, Hyderabad and Impacts of Industries Closure", International Journal of Scientific \& Engineering Research (IJSER) 7 1315-1319. 2016.7.1315.

11. Sujatha. M, N. Rama Rao, T. Satyanarayana, SS. Asadi,K. Siva Kishore Babu (2016), "Assessment of ground water pollution along thippagunta drain in prasadampadu, Vijayawada rural , Krishna distract, Andhra Pradesh", IJCIET, 7(6), 738-746. 2016.7.6.738.

12. Subhajyoti. Das, (2011), "Cleaning of the Ganga", Journal Geological Society of India,.78,.124-130. 2011.78. 124.

13. Samba SR, Manjunath A, Ramesh K, Hima Bindu Y, Sarada Devi M (2017), "Assessment of ground water quality Saroornagar Mandal, $\mathrm{Rr}$ District,Telangana State", International Journal of Creative Research Thoughts , 5 , 777-786. 2017.5.777.

14. Syeda AU, Nurul H (2013), "Assessment and evaluation of the quality of drinking water at the consumer end- A study of Hyderabad, Andhra Pradesh" , International Journal of Plant, Animal and Environmental Sciences, 3, 50-54. 2013.3.50. 